\title{
Two Futures of Educational Reform: What Strategies will Improve Teaching and Learning?
}

\section{Linda Darling-Hammond}

This article compares the impact of recent educational reforms on school outcomes in several countries around the world. It argues that educational reforms based on conceptions of equity and capacity-building focusing on high-quality teaching and learning systems and access to good instruction for all students have proved to be more successful than educational reforms based on competition, incentives and sanctions.

In the last decade, mountains of reports have been written in countries around the world about the need for education reform. Generally, what grounds these calls for reform is the belief that schools need to be reorganized to produce more powerful learning focused on the demands of life, work, and citizenship in the $21^{\text {st }}$ Century. In the United States, for example, like many other industrialized nations, at least $70 \%$ of jobs now require specialized knowledge and skills, as compared to only $5 \%$ at the dawn of the last century, when our current system of schooling was established. These new skills include the capacity to

- Design, evaluate, and manage one's own work so that it continually improves;

- Frame, investigate, and solve problems using a wide range of tools and resources;

- Collaborate strategically with others;

- Communicate effectively in many forms;

- Find, analyze, and use information for many purposes; and

- Develop new products and ideas.

As they entered the $21^{\text {st }}$ century, most nations around the world were responding to changing economic, demographic, political, and social imperatives. Nearly all countries are engaged in serious discussion of school reform to address demands for much higher levels of education for much greater numbers of citizens demands created by a new information age, major economic shifts, and a redefinition of democracy around the globe. These demands are often being imposed upon educational institutions designed a century ago for a different time. The need to prepare future citizens and workers who can cope with complexity, use new technologies, and work cooperatively to frame and solve novel problems - 
and the need to do this for a much more diverse and inclusive group of learners - has stimulated efforts to rethink school goals and curriculum, to better prepare teachers, and to redesign school organizations.

Though political enthusiasm for reform seems boundless, there is good reason for caution. What kind of reform? Toward what end? Using what policy strategies in what ways? With what supports and resources? And with what attention to side-effects?

A thoughtful response will be needed as the pace of change quickens. Today's rapidly changing economic base has stimulated political concerns as well as rapid job changes. Whereas during much of the 20th century, most workers held 2 or 3 jobs during their lifetimes, the U.S. Department of Labor (2006) estimates that today's workers hold more than 10 jobs before they reach the age of 40 . The top ten in-demand jobs projected for 2010 did not exist in 2004 (Gunderson, Jones \& Scanland, 2004). Thus, we are currently preparing many students for jobs that do not yet exist using technologies that have not yet been invented to solve problems that we don't even know are problems yet.

Manufacturing industries can no longer pay high wages for low-skilled work. High wages and corporate growth characterize industries that rely on high levels of skill, complex technologies, and new knowledge and information. "An economy in which knowledge is becoming the true capital and the premier wealth-producing resource» means that "once again we will have to think through what an educated person is» (Drucker, 1989, p. 232).

Meanwhile, knowledge is expanding at a breathtaking pace. It is estimated that 5 exabytes of new information (about 500,000 times the volume of the Library of Congress print collection) was generated in 2002, more than 3 times as much as in 1999. Indeed in the four years from 1999 to 2003, the amount of new information produced approximately equaled the amount produced in the entire history of the world previously (Varian \& Lyman, 2003). The amount of new technical information is doubling faster than every two years (Jukes \& McCain, 2002). As a consequence, effective education can no longer be focused on the transmission of pieces of information that, once memorized, comprise a stable storehouse of knowledge. Education must help students learn how to learn in powerful ways, so that they can manage the demands of changing information, technologies, jobs, and social conditions.

\section{1st Century Schools Confront New Demands}

How can nations provide education that will develop these more complex skills - not just for a small slice of students who have traditionally been selected for the kind of ambitious learning represented in elite schools and advanced programs, but for the vast majority of children? How can they move from the industrial 
model approach to education designed at the end of the $19^{\text {th }}$ century to one that is pointed clearly and unambiguously at the demands of the $21^{\text {st }}$ ?

What we now think of as $21^{\text {st }}$ century thinking and problem-solving skills are not new abilities (with the exception of the addition of computers), but they were not envisioned for most students in the school systems designed a century ago as societies moved from agrarian economies to urban manufacturing economies. Those systems were based on the factory model made popular in the new industrial age. The notion was that one could organize all of the facts needed into a set body of knowledge and divide it up neatly into the twelve years of schooling, doling out the information through graded textbooks and testing it regularly. Automated means for mass producing goods created specialized divisions of labor and a proliferation of routinized, semi-skilled jobs requiring limited knowledge. «Scientific management» brought with it a distinct division of responsibility between a new class of managers, who were to do the thinking, and the workers, who were to follow procedures developed by the managers (Callahan, 1962, pp. 37-38).

This approach was carried over from manufacturing industries to schools, which sought to select and sort students into differentiated tracks leading to very distinctive kinds of work.

These tracking systems provide a basic skills curriculum to most children, and a more thinking-oriented curriculum to a few, who were taught in separate schools or curriculum tracks - a system that has remained firmly in place in many countries - although not those that have had the greatest strides in overall achievement.

Teachers, like factory workers, were often viewed as semi-skilled workers who would implement a set curriculum, rather than developing lessons tailored to the needs of their students. Rather than investing in highly knowledgeable teachers, 20th-century education policy often assumed that continually improving the design specifications for schoolwork - required courses, tests, texts, and management systems - would lead to student learning.

This kind of schooling system may have worked reasonably well many decades ago for helping most students acquire minimal basic skills and preparation for routine work, and for enabling a few to develop higher order thinking and performance skills. However, it has proved increasingly inadequate to the new mission of schools: teaching large numbers of very diverse learners to think critically, solve complex problems, and master ambitious subject matter content - a task that requires a different, more sophisticated kind of teaching than merely covering the curriculum or "getting through the book» (Darling-Hammond et al., 2008).

As nations transform their education systems, however, there are different theories of action and approaches to reform that are likely to lead to very different directions. I will argue that reforms based on new conceptions of equity and capacity-building have already proved to be more successful than those based on competition and incentives, on seeking to motivate individuals and 
schools through rewards \& sanctions. Furthermore those that have consciously built high-quality teaching and learning systems that focus on access to good instruction for all students have been more successful than that have tried to implement a wide array of on-and-off-again innovations, pilots, and one-off solutions that take a lot of energy to create and that are neither sustained nor scaled up.

I will further argue that the issues of how to enact standards for teaching and learning, a centerpiece of many reforms, are not so much the commonly debated issues of standards versus no standards, or centralization versus decentralization, or even testing versus not testing, but matters of what kind of standards and what kinds of curriculum and assessment strategies. What kind of learning do they represent for students and what kind of learning do they support for students and schools? Do they build knowledge, capacity, and expertise across the system, or do they encourage competition, isolation, and gaming? What roles are there for educators in enacting meaningful teaching and engaging in collective learning? What roles are there for educators, parents, and students to engage in the proactive development of ever more creative and inventive schools flexible enough to meet tomorrow's needs? Do they introduce rigor - as in rigor mortis - or quality that sustains continuous improvement and adaptation to the world of change we must confront?

\section{Reform Based on Equity and Capacity-Building}

In broad strokes, I will first argue that a focus on both capacity-building and equity are central to successful versions of reform. The nations that have experienced the most dramatic increases in educational attainment and achievement - and the greatest equity in educational outcomes - have consciously expanded educational access to a «thinking curriculum» to more and more of their people, while revising curriculum, instruction, and assessment to support the more complex knowledge and skills needed in the $21^{\text {st }}$ century. Four high achieving nations on PISA - Canada, Finland, Singapore, and South Korea have all used similar strategies.

Finland has been the darling of educational reform buffs since it surprised many by being the highest performing OECD nation on the PISA exams since the international assessments were instituted in 2000. Once a mediocre and highly inequitable education system, it completely overhauled its system starting in the 1980s, when it emerged from the Soviet Union's shadow. The first step was to dismantle the rigid testing and tracking system that had allocated differential access to knowledge to its young people, replacing them with highlytrained teachers and curriculum and assessments focused on problem-solving, creativity, independent learning, and student reflection. What Finland realized is that teachers could have great autonomy to teach a very lean national curri- 
culum - with no external assessments used to manage teaching and learning - if they were extremely well-prepared. Teacher education was completely overhauled, and «learning to learn» is the central focus of education. «Intelligent accountability» is managed by ongoing evaluation of teaching and learning with lots of feedback to practitioners within and across schools and the system as a whole. These changes have propelled achievement to the top of the international rankings and closed what was once a large, intractable achievement gap (Sahlberg, 2009).

Similarly, in the space of one generation, South Korea moved from a nation that educated less than a quarter of its citizens through high school to one that now graduates $95 \%$ from a full high school education and sends $80 \%$ of these graduates to postsecondary education, ranking third in the world in college-educated adults and among the top in student achievement as well (DarlingHammond, 2010). Like Finland, Korea dismantled an intensive tracking system based on an intricate series of high-stakes tests throughout the system that had prevented many students from moving on in their education. Now the only mandated external test is at 12th grade for admission to university. Investments in building a strong teaching force and expanding access to challenging curriculum went hand in hand.

In like fashion, Singapore began to transform itself in the 1970s from a collection of swampy fishing villages into an economic powerhouse by building an education system that would ensure every student access to strong teaching, an inquiry curriculum, and cutting-edge technology. Like Korea, Singapore has created a high and equitable level of achievement among its citizens, despite high levels of poverty. Although Singapore, for example, is a nation in which $80 \%$ of families live in public housing, its students scored among the top few nations in the world on the PISA assessments. When children leave the tiny, spare apartments they occupy in high-rises throughout the city, they arrive at beautiful, well-stocked school buildings where teachers are uniformly well-trained and well-supported and the curriculum is increasingly focused on innovation, creativity, and higher-order thinking skills.

The successful improvements efforts in Ontario, Canada - which have made it one of the highest-performing, highly diverse jurisdictions in the world, with steep increases in graduation rates and achievement - have focused on teacher and leader professional development, and supporting collective action within and across schools toward improvement by disseminating research and best practices across schools, recognizing and sharing school achievements, and rewarding cooperative progress. The goal, as Ontario's former deputy minister, Ben Levin put it, has been steady improvement rather than erratic innovation.

\section{A Whole System Focus}

The nations that have most dramatically improved education have undertaken these elements of reform in a systemic fashion, rather than pouring energy into 
an ever-changing array of innovations and fads that change with the political winds every few years, as has often been the case in the United States. And while small nations have conducted this work from a national level, similar strategies have been successfully employed at the state or provincial level in high-scoring Australia, Canada, and New Zealand, and regions such as Shanghai, Hong Kong and Macao in China. They demonstrate how it is possible to build a system in which students are routinely taught by well-prepared teachers who are given time to collaboratively reflect on and refine the curriculum, supported by appropriate materials and assessments that foster learning for students, teachers, and schools alike.

The issue is not the level at which the reform occurs (national, state, or local) but the nature of the goals and supports put in place. As Michael Fullan (2011) has argued "whole system reform" - whether of a state, province, region, canton, or an entire country - must focus on all of the aspects and all of the schools in a system, and if it is to be successful, it must:

1. foster intrinsic motivation of teachers and students;

2. engage educators and students in continuous improvement of instruction and learning;

3. inspire collective or team work; and

4. affect all teachers and students -100 per cent.

Regardless of the governance scheme, the ability to create a dynamic, successful system of schools rests on the professionalization of teaching. "The key to system-wide success,» Fullan notes, «is to situate the energy of educators and students as the central driving force. This means aligning the goals of reform and the intrinsic motivation of participants. Intrinsic energy derives from doing something well that is important to you and to those with whom you are working. Thus policies and strategies must generate the very conditions that make intrinsic motivation flourish. This is as basic as the human condition.... Policies and strategies that do not foster such strong intrinsic motivation across the whole system cannot be a source of whole system reform. Furthermore, strategies that do not develop increased capability ... are similarly destined to failure» (Fullan, 2011, p. 3). Strategies that work build capacity, mobilize collective efforts, invest in instruction, and attend to quality and equity in the entire system, not just to individual educators, schools, or innovations.

\section{Supports for High Quality Teaching}

In these and other high-achieving nations, supports for high-quality teaching are key. A study of twenty-five of the world's school systems, including ten of the top performers, found that investments in teachers and teaching are central to improving student outcomes. These focus on purposeful recruitment; preparation and development; and systemic supports for instruction (Barber \& Mourshed, 2007). The highest-achieving countries around the world routinely prepare their teachers extensively, pay them well in relation to competing occupations, and 
provide them with lots of time for professional learning. They also distribute well-trained teachers to all students - rather than allowing some to be taught by untrained novices - by offering equitable salaries, sometimes adding incentives for harder-to-staff locations.

Leaders in Finland attribute the nation's gains to their intensive investments in teacher education. Over ten years the country overhauled preparation to focus more on teaching for higher-order skills like problem solving and critical thinking. Teachers learn how to create challenging curriculum and how to develop and evaluate local performance assessments that engage students in research and inquiry on a regular basis. Teacher training emphasizes learning how to teach students who learn in different ways - especially including those with special needs. The egalitarian Finns reasoned that if teachers learn to help students who struggle, they will be able to teach all students more effectively (Buchberger \& Buchberger, 2004).

All teachers - including primary school teachers - now receive two to three years of graduate-level preparation for teaching, completely at government expense, including a living stipend. Typically, programs include at least a full year of training in a «model school» connected to the university, like the professional development school partnerships created by some U.S. programs, along with extensive coursework in pedagogy and a thesis researching an educational problem in the schools. Unlike the U.S., however, where teachers either go into debt to prepare for a profession that will pay them poorly, or enter with little or no training - Finland - like Canada, Singapore, Korea, and other countries made the decision to invest in a uniformly well-prepared teaching force by recruiting top candidates and paying them to go to school.

Slots in teacher training programs are highly coveted and shortages are rare. They raised standards and supports for entering teaching, rather focusing exclusively on salaries - which are, in fact, reasonable but not all that high. What makes teaching - especially primary school teaching - the most desired profession in Finland (only 10\% of applicants can be accepted), is that teachers are so well prepared that they feel efficacious and effective in their work, they are highly respected for their expertise, and they therefore are trusted with so much autonomy to do what they feel is best for students.

Policymakers' decision to invest in very skillful teachers and to allow local schools more autonomy to make decisions about what and how to teach was 30 years ago - a reaction against the oppressive, centralized system they sought to overhaul. I wonder if that decision could have been made today, given the theories of action that are now current. However, this bet seems to have paid off. Teachers are sophisticated diagnosticians, and they work together collegially to design instruction that meets the demands of the subject matter as well as the needs of their students. Finnish schools are not governed by external standardized tests - which are not required at any grade level - but by teachers' strong knowledge about how students learn (Laukkanen, 2008). 
Top-ranked Singapore, by contrast, is more centralized, and it does offer examinations at grades 6 and 9, as well as high-school leaving examinations (something I will return to), but it treats teaching similarly. Singapore's Institute of Education - the tiny nation's only teacher training institution - is investing in teachers' abilities to teach a curriculum focused on critical thinking and inquiry - the $21^{\text {st }}$ century skills needed in a technologically oriented economy. To get the best teachers, students from the top $1 / 3$ of each graduating high school class are recruited into a fully paid 4-year teacher education program (or, if they enter after they have already completed college, a one- to two-year graduate program) and immediately put on the Ministry's payroll, receiving nearly a full salary. When they enter the profession, teachers' salaries are comparable to those of engineers and other highly-paid professionals.

As in other highly-ranked countries, novices are not left to sink or swim. Expert teachers are given released time to serve as mentors to help beginners learn their craft. The government pays for 100 hours of professional development each year for all teachers in addition to the 20 hours a week they have to work with other teachers and visit each others' classrooms to study teaching. Currently teachers are being trained to undertake action research projects in the classroom so that they can examine teaching and learning problems, and find solutions that can be disseminated to others. Teachers are involved in developing and scoring all of the examinations (which are completely open-ended and increasingly performance-based) and in developing curriculum, so they deeply understand and «own» the process of developing learning.

And teachers continue to advance throughout the career. With help from the government, Singapore teachers can pursue three separate career ladders that help them become curriculum specialists, mentors for other teachers, or school principals. These opportunities bring recognition, extra compensation, and new challenges that keep teaching exciting.

In these and other high-achieving countries, schools are organized to support teacher success. Typically, teachers have 15 to 20 hours a week to work with colleagues on developing lessons, participating in research and study groups, and engaging in seminars and visits to other classrooms and schools.

\section{A Focus on Higher-Order Learning}

Having well-prepared teachers who focus on continually improving instruction is only part of building an educational system that can respond to $21^{\text {st }}$ century needs. Teachers need to work with students on critical skills that will allow them to transfer and apply their knowledge to new situations, and enable them to learn how to learn. The transmission curriculum that dominated schools for the last 100 years - which assumed a stable body of knowledge could be codified in textbooks and passed onto students who could "learn" it by remembering all the facts - is counterproductive today. Rigid approaches to defining knowledge cannot accomplish what is currently needed. Today's 
students need an education that will help them learn how to learn in powerful ways, so that they can manage the demands of changing information, knowledge bases, technologies, and social conditions.

The most successful countries have been moving away from a curriculum that is overly prescribed and managed by tests that focus on recall and recognition, toward the production and application of knowledge. Korea and Singapore are thinning the curriculum (Singapore's recent motto has been «teach less, learn more») in an attempt to ensure that students will have a chance to engage deeply in inquiry-based learning. The goal is to teach fewer topics each year and teach them more thoroughly so students build a stronger foundation for their learning. Singapore's emphasis on innovation and inquiry has led to requirements for extended science investigations, research papers, and project-based learning - including cooperative problem-solving, that are built into the examination system. Hong Kong has replaced its traditional examination system with schoolbased assessments that favor project-based learning and portfolios.

While there has been a move in countries like the U.S. and Australia to centralize curriculum and testing decisions, in the belief that this will make teaching and learning more comparable, the real question about curriculum should not be whether it is national, state, or local, but whether it is focused on the right kind of learning and connected to a system that supports sophisticated instruction. Curriculum and assessments must focus on critical thinking and problem solving, whether developed nationally, at the state or provincial level, or locally. The key issue is to look inside the black box of standards and assessment and ask what kind of learning is being called for, how empowered students will be to learn in complex, meaningful ways, and how empowered teachers will be to engage in powerful teaching and learning.

Consider the difference between this multiple-choice item on a typical U.S. test and one I will show you from the Queensland system of «rich tasks.»

1. What two gases make up most of the Earth's atmosphere?

A) Hydrogen and oxygen

B) Hydrogen and nitrogen

C) Oxygen and carbon dioxide

D) Oxygen and nitrogen 


\section{Science and Ethics Confer}

Students must identify, explore, and make judgments on a biotechnological process to which there are ethical dimensions. They must select such a process and:

1) undertake laboratory activities that help them understand some of the laboratory practices.

2) Provide a written explanation of the fundamental technological differences in some of the techniques used in this area.

3) Consider the range of ethical issues raised and present a deep analysis of an ethical issue about which there is a debate in terms of an ethical framework.

4) Select six real-life people who have made relevant contributions to this area and write a 150-200 word précis about each one indicating his/her contribution, as well as a letter of invitation to one of them to an international conference.

I fear that this kind of work in Queensland - along with the science investigations students need to design, carry out, analyze, and report on - will soon be extinct with the Australian decision to adopt the limiting multiple-choice testing technology for its national test, and to begin tying school and teacher accountability to that test. What we have learned in the United States is that what gets counted counts, even if it doesn't matter for high-quality learning. 85\% of teachers in the U.S. believe high-stakes testing has distorted and undermined the quality of learning. The nature of standards and assessments matters - what they measure and how they are implemented have much to do with the ultimate quality of education systems.

\section{Equitable Funding}

Finally the top-performing and steeply improving nations fund schools adequately and equitably across jurisdictions, and add incentives for teaching in high-need schools. All three nations have built their education systems on a strong egalitarian ethos, explicitly confronting and addressing potential sources of inequality. In South Korea, for example, a wide range of incentives is available to induce teachers to serve in rural areas or in urban schools with disadvantaged students. In addition to earning bonus points toward promotion, incentives for equitable distribution of teachers include smaller class sizes, less in-class teaching time, additional stipends, and opportunities to choose later teaching appointments. The end result is a highly qualified, experienced, and stable teaching force in all schools, providing a foundation for strong student learning. 


\section{Reform Based on "Accountability" and Incen- tives}

In contrast with the steeply improving systems that have made rapid, purposeful progress in professionalizing teaching and improving access to high-quality instruction, some other countries have adopted an agenda that rests on a marketbased strategy to school governance coupled with a top-down, test-driven approach to educational change that relies heavily on extrinsic motivators - carrots and sticks - and invests little in teachers' or schools' capacities for improvement. This strategy has characterized the United States for more than a decade, since the passage of the No Child Left Behind law, as well as new initiatives in Australia and Great Britain, and, in some respects, efforts in countries like Sweden and Chile, which engaged in substantial privatization that increased inequality and reduced overall achievement.

Although wealthy countries, all, in terms of gross national product, these nations have, in all cases but Australia, lower levels of success than their wealthy peers, and much more unequal outcomes for their students. Australia's relative success predates the new reforms that are beginning to re-shape that nation's system through nationally mandated standardized tests, increasingly tied to rewards and sanctions for educators and schools; increasing inequality of educational funding between the public and growing private sector; and efforts to individualize and de-professionalize teaching through merit pay and initiatives to encourage entry of untrained individuals into the profession. All of these are strategies borrowed from the United States, which, in turn, borrowed them from Thatcher's reforms in England - which are cycling around once again with the new government there.

The heavy use of extrinsic incentives assumes that the major problem in education is that schools and teachers are not trying hard enough - that they are withholding their efforts - and that rewards or threats of sanctions (in the form of job actions, merit pay, and threats to shame and close schools) will motivate them to work harder. Competition - between and among teachers and between and among schools - is intended, as well, to motivate greater effort and to create improvement. This strategy does not consider that educators may already be working hard, but that they do not have the knowledge, skills, or resources to be successful. Nor does it consider that collaborative effort and sharing of knowledge - both among teachers and across schools - might allow learning to grow throughout the system and enable the whole to be greater than the sum of the parts.

Fullan (2011) calls these market-based approaches the "wrong drivers» for education reform. He singles out especially the use of test results and teacher evaluation to reward or punish teachers and schools, rather than building capacity; a focus on individual rather than group solutions and on fragmented strategies (like charter schools or one-note short term innovations of various kinds) rather 
than integrated or systemic strategies; and a blind faith that technology will somehow magically change learning, without a focus on instruction.

I would add to his list, a lack of attention to resource equity - both the resources of dollars and those of highly-qualified teachers and high-quality curriculum - and a failure to focus on building systems that can ensure that all educators have the skills they need while all schools have the conditions available to support good teaching.

In England, the use of testing and league tables to drive reform led to increased exclusion of struggling students from schools, while reduced investments in university-based teacher education led to a less-skilled teaching force. One study of the outcomes found that student exclusions were highest in schools where teaching capacity was the lowest - where, in fact, inexperienced and underprepared educators simply did not know how to achieve better results, other than by getting rid of struggling students (Rustique-Forrester, 2005). Overall, achievement suffered and became more inequitable. A number of other jurisdictions in the UK and in Asia banned the use of League tables in their reform initiatives as a result. Labor government changes that sought to replace rankings with capacity-building at the school level are now at risk with a new government and the pendulum swings that have characterized policy in many English-speaking countries that have strong political control of education.

The U.S. now has a full decade of results to examine for the outcomes of these kinds of initiatives, and they are similar: While state test scores - driven by strong threats and sanctions - have improved, national assessment results have stagnated and international results have dropped. Curriculum has been narrowed as schools focus on multiple-choice tests of low-level skills in reading and math, tied to rewards and sanctions for schools and teachers. Students are engaged in less interesting and meaningful work, do less writing and research, and, as a result, are less prepared for college and careers. Student pushouts and dropouts have increased as schools seek to eliminate those who will bring their scores down, and students in high-need schools are increasingly likely to have a revolving door of inexperienced and untrained novices, who are admitted to teaching in low-income districts through backdoor routes into the profession (Darling-Hammond, 2010). The National Research Council has just published a report, based on a review of two decades of research, documenting the lack of success of test-based accountability strategies. Other studies have documented the negative effects on student learning and teacher retention of alternative routes into teaching that truncate coursework and that skip the opportunity for guided clinical experience (Darling-Hammond, 2010).

Despite little evidence of success, this approach has been reinforced in the new «Race to the Top» initiatives - which award competitive grants to states to expand these alternative routes into teaching, offer merit pay tied to student test scores, require the creation of more charter schools, and re-staff or terminate schools that serve high-need students and have low achievement. 
These strategies go straight to the periphery of the issues, bearing little resemblance to the systemic investments that have characterized major improvements in education systems at home and abroad. No nation has become high-achieving by sanctioning schools based on test-score targets and closing those that serve the neediest students. No nation has closed the achievement gap without investing in adequate resources and quality teaching. The implementation of Race to the Top has not required states to equalize funding to under-resourced schools or even to maintain their existing commitments to these schools, many of which have had to slash budgets deeply, laying off tens of thousands of teachers, raising class sizes to over 40 in some cases, and cutting previously successful programs.

Race to the Top's requirement that states expand charter schools is unaccompanied by policies to assure quality and ensure access, despite evidence from the largest national study (CREDO, 2009) that charters more frequently underperform than outperform their counterparts serving similar students, while failing to serve special education students and exacerbating racial segregation. While some excellent charters exist, along with excellent schools run by regular public school districts, the law does not aim to spread excellence so much as to change governance. And any successes that charters do achieve have little effect on the system as a whole, since traditional schools - which are increasingly hyperregulated - do not typically have the flexibility or the resources to implement these approaches. Nations that are focused on spreading quality like Singapore, Finland, and Canada, for example - have developed strategies for schools to share successful practices through research and practice networks that have created an engine for ongoing improvement for the system as a whole.

Rather than creating a framework for dramatically improving the knowledge, skills, and equitable distribution of teachers, as high-achieving nations have done, Race to the Top encourages states to reduce coursework for prospective teachers, despite findings that teachers from low-coursework alternatives actually reduce student achievement (Darling-Hammond, 2010). Despite the productive innovations used in some of the top quality teacher education programs, there is no effort to learn about, invest in, or scale up these programs more widely, or to enable candidates to enter and complete high quality programs. Race to the Top largely misses the critical investments needed to prepare and distribute excellent teachers and school leaders. Removing low-performing teachers cannot improve teaching or student outcomes without strategies to ensure a stable supply of highly effective teachers who stay in all communities.

Pay bonuses alone cannot succeed in recruiting and retaining teachers without efforts to create competitive, equitable salaries and working conditions. Indeed, merit pay has come and gone regularly since the 1920s, running into many problems, including the fact that it does not support knowledge growth and sharing among teachers. A major experimental study in the US recently found no positive effects on achievement from bonuses tied to student test scores (Springer et al., 2011), and another study of Portugal's efforts to tie teacher pay to student 
test scores found that the system appeared actually to decrease student achievement. The researcher hypothesized that this form of merit pay likely reduced teacher collaboration to the detriment of student learning (Martins, 2009).

While teacher evaluation needs to become more rigorous, and rewards for effectiveness should be encouraged, these strategies can only succeed if they are embedded in a system of universal high-quality preparation, mentoring, and support - including well-designed schools that allow and enable good practice. Rather than short-term incentives and quick fixes, policy making must focus on building capacity across the entire system.

When the primary drivers of reform are competition and sanctions, rather than capacity-building and strategic investments, it is impossible to build good schools in every community. For whole system reform to occur, reforms must couple thoughtful standards and meaningful assessments with resources that enable educator knowledge and high-quality practice. Ironically, test-based accountability of the sort we have seen in the US and the UK - and are beginning to see in Australia - renders schools less accountable for high-quality practice, as beating the test by narrowing the curriculum or getting rid of students becomes the goal rather than promoting powerful learning.

So what should we do to foster productive educational reform? There is no one right way to engage in change, but here is some advice:

1. Get inside the black box: If you decide you pursue standards and assessments as one part of a broader a strategy, be sure the standards are focused on meaningful learning that truly prepares students for independent learning, inquiry, and problem-solving. Value assessments that are not artificial proxies for this kind of learning but that actually allow students to engage in serious intellectual and practical work and place teachers in the role of designers, developers, and evaluators of this learning, with the kind of moderation of results that creates consistency without trivializing learning. Favor assessments of, as, and for learning, and use them to inform curriculum and professional development - not as arbiters of sanctions and punishments

2. Think system: Understand that changing expectations of schools means changing the design of schools and systems as well. Pursuing a single idea for reform - like adding standards and assessments - without changing the other aspects of schooling that are related to it (how curriculum is organized, how time is used, adults and students are grouped together, how opportunities for learning are constructed, how teachers are trained and supported) is like pulling on a single thread in a tapestry: the result is a tangle instead of a more beautiful surface. Every organization is designed to get the results that it gets. Different results require more than doing the same thing harder. Invite educators to consider how the design of schooling must evolve to achieve the new goals, and empower them to work collectively to achieve it. Be sure that efforts to scale-up what works focus on all students and schools, not just a few. 
3. Focus on instructional quality: Build knowledge and expertise for teaching and systems to spread it. There is much to learn from the best teacher education and development programs in the world. It is true that some teachers are better prepared than others. Find out what is working and figure out how to scale it up. In the U.S. we have some evidence on this score. The most effective programs focus on high-quality, intensive clinical experiences where good practice is modeled; tie coursework directly to tools for practice and opportunities to apply learning; ensure a strong understanding of content and subject-specific pedagogy; study curriculum deeply; and use portfolios of practice to guide and evaluate teaching. Some of these portfolios - like the National Board Certification process and a new performance assessment for beginning teachers - ask teachers to demonstrate with artifacts, videos of their classrooms, and commentary how they plan curriculum for diverse learners, implement and evaluate instruction, assess students, provide feedback, and understand their learning. We have seen that these kinds of assessments, used system-wide, can transform teaching and the process of learning to teach, providing grist for preparation and mentoring programs to improve their work as well. When you've developed great teaching, find ways to share it.

4. Leverage the right work: If you must create incentives, incentivize collective, collegial efforts to improve instruction - and to develop stronger schools and systems, rather than individualistic approaches that pit schools and teachers against one another and reduce the learning that can and must occur. Empower people to learn and improve their work, and appreciate them when they do. That can provide the foundation for productive reform.

5. Reflect and revise: Whatever you do will be more successful if educators know that a continual process of reflection, evaluation, revision, and improvement will occur and that their insights will be a major part of that process. Intelligent accountability will result from a robust learning system that figures out how to maximize the probability of good practice, identify and minimize the harm from problematic efforts, and ensure a continual loop for feedback and learning.

Of course, it goes without saying - but probably needs to be said -- that each system should acknowledge and build upon the strengths it already has in place. Too many reformers think their job is to throw away what has come before and start over with a brand new idea. We know that this kind of change rarely lasts, and leads to pendulum swings in policy. The great American educator, Horace Mann, once said, "Where anything is growing, one former is worth a thousand reformers.» If we can focus on forming strong schools where exciting and empowering teaching and learning go on, rather than pursuing the Holy Grail of reform, then perhaps we will be doing something.

\section{References}


Barber, M. \& Mourshed, M. (2007). How the world's best-performing school systems come out on top. London: McKinsey and Company.

Berliner, D. C. \& Biddle, B. J. (1995). The manufactured crisis. New York: Addison-Wesley.

Buchberger, F. \& Buchberger, I. (2004). Problem solving capacity of a teacher education system as condition of success? An analysis of the "Finnish case». In F. Buchberger \& S. Berghammer (Ed.), Education policy analysis in a comparative perspective (pp. 222-237). Linz: Trauner.

Callahan, R. E. (1962). Education and the cult of efficiency. University of Chicago Press.

Credo (2009). Rigorous research to improve public education. Retrieved June 18, 2012, from http://credo.stanford.edu/index.html.

Darling-Hammond, L. (2010). The flat world and education: How America's commitment to equity will determine our future. New York: Teachers College Press.

Darling-Hammond, L., Barron, B., Pearson, P. D., Schoenfeld, A., Stage, E. K., Zimmerman, T. D., Cervetti, G. N. \& Tilson, J. L. (2008). Powerful Learning: What we know about teaching for understanding. San Francisco: Jossey-Bass.

Drucker, P. F. (1989). The new realities. New York: Harper \& Row.

Fullan, M. (2011). Choosing the wrong drivers for whole system reform. Melbourne: Center for Strategic Education.

Gunderson, S., Jones, R. \& Scanland, K. (2004). The jobs revolution: Changing how America works. Copywriters, Inc.

Jukes, I. \& McCain, T. (2002, June). Living on the future edge. The InfoSavvy Group and Cyster.

Laukkanen, R. (2008). Finnish strategy for high-level education for all. In N. C. Soguel \& P. Jaccard (Ed.), Governance and performance of education systems (pp. 305-324). Dordrecht: Springer.

Martins, P. (2009). Individual teacher incentives, student achievement and grade inflation (Paper No. 4051). London, UK: Queen Mary, University of London, CEG-IST \& IZA.

Rustique-Forrester, E. (2005). Accountability and the pressures to exclude: A cautionary tale from England. Education Policy Analysis Archives. Retrieved June, 2012, from http://epaa. asu.edu/ojs/article/view/131/257

Sahlberg, P. (2009). Creativity and innovation through lifelong learning. Lifelong Learning in Europe. 14(1), 53-60. Retrieved June 18 2012, from http://www.pasisahlberg.com/ downloads/Creativity\%20and\%20innovation\%20in\%20LLL\%202009.pdf

Sanders, W. L. \& Rivers, J. C. (1996). Cumulative and residual effects of teachers on future student academic achievement. Knoxville, TN: University of Tennessee, Value-added research and assessment center. Retrieved June 11, 2012, from http://www.mdk12.org/ practices/ensure/tva/tva_2.html

Springer, M., Ballou, D., Hamilton, L., Le, V., Lockwood, V., McCaffrey, D., Pepper, M. \& Stecher, B. (2010). Teacher pay for performance: Experimental evidence from the project on incentives in teaching. Nashville, TN: Vanderbilt University, National center on performance incentives.

U.S. Department of Labor. (2006). Number of jobs held, labor market activity, and earnings growth among the youngest baby boomers: Results from a longitudinal survey. Washington, DC: Bureau of Labor Statistics. Retrieved September, 22, 2007, from http://www.bls.gov/ news.release/pdf/nlsoy.pdf

Varian, H. \& Lyman, P. (2003). «How Much Information? 2003». UC Berkeley School of Information Management \& Systems (SIMS). Retrieved September, 22, 2007, from www2.sims.berkeley.edu/research/projects/how-much-info-2003/printable_report.pdf

Wilson, S., Floden, R. \& Ferrini-Mundy, J. (2002, February). Teacher preparation research: Current knowledge, gaps, and recommendations. Working paper. University of Washington, Center for the study of teaching and policy. 
Key words: Educational reform, teaching, learning, standards, instruction

\section{Zwei zukünftige Bildungsreformen: Welche Strategien verbessern Lehren und Lernen?}

\section{Zusammenfassung}

Dieser Artikel vergleicht die Bildungsreformen jüngeren Datums in mehreren Ländern und analysiert deren Einfluss auf die Qualität der Lehr- und Lernprozesse. Es wird argumentiert, dass Reformen, die auf Konzepten der Gerechtigkeit und Kompetenzentwicklung basieren, die auf qualitativ hochstehende Unterrichtsprozesse und -systeme fokussieren und die den Zugang aller Schüler/innen zu gutem Unterricht sicher stellen, erfolgreicher sind als Reformen, die auf Konkurrenz, Anreizen und Sanktionen basieren.

Schlagworte: Bildungsreform, Lehren, Lernen, Standards, Unterricht

\section{Deux avenirs pour les réformes scolaires: quelles stratégies améliorent l'enseignement et l'apprentissage ?}

\section{Résumé}

Cette contribution consiste à comparer les effets de réformes scolaires implémentées plus ou moins récemment dans plusieurs pays et dans le monde.

L'auteure y démontre que les réformes fondées sur des principes d'équité et de compétences qui mettent la priorité sur des systèmes d'enseignement et d'apprentissage de haute qualité accessibles par tous les élèves, produisent de meilleurs effets que des réformes scolaires fondées sur la compétition, les récompenses et les sanctions.

Mots clés: Réforme scolaire, innovation scolaire, enseignement, apprentissage, standards. 


\section{Due futuri per le riforme educative: Quali strategie per migliorare l'insegnamento e l'apprendimento?}

\section{Riassunto}

Questo articolo confronta l'impatto di alcune recenti riforme educative in diversi paesi del mondo in base alla qualità dei processi di apprendimento e di insegnamento. L'articolo sostiene che le riforme educative basate su una visione di equità e di sviluppo di competenze, e che si concentrano su sistemi formativi di alta qualità e sull'accesso a una valida offerta formativa per tutti gli studenti sono risultati più efficaci rispetto a riforme basate sulla competizione e su sistemi di incentivi e sanzioni.

Parole chiave: Riforme educative, insegnamento, apprendimento, standard, formazione 